\title{
Substrate for cupuaçu plantlets and the influence of cow urine as biofertilizer
}

\begin{abstract}
Anapaula de Paula Cidade Coelho ${ }^{1}$, Paulo Cesar Lima Marrocos², Marcelo Schramm Mielke ${ }^{3}$, Martielly Santana dos Santos ${ }^{4}$, Cibele Merched Gallo ${ }^{5}$, Eduardo Gross ${ }^{6 *}$

Abstract - The use of organic waste as components of substrate to produce fruit plantlets provides alternative materials, easily available and low cost. The aim of this work was to evaluate the effect of substrate and biofertilization with cow urine on the growth of cupuaçu plants (Theobroma grandiflorum) in an organic production system. A factorial experiment was conducted in a completely randomized design with 12 replications including four types of substrates (base mixture; base mixture + coconut fiber; base mixture + cocoa shell and base mixture + sand) with or without biofertilizer application totalizing 96 experimental units. Substrate and biofertilizer influenced the gas exchange and growth of $T$. grandiflorum plants. The interaction between these two factors significantly affected the dry matter, relative growth rate, net photosynthetic rate, and content of $\mathrm{P}, \mathrm{K}$ and $\mathrm{Mn}$ in the leaves. Each factor, substrate and of cow urine application, independently, influenced the chlorophyll index, the leaf area, diameter, and height of the cupuaçu plants and the contents of $\mathrm{N}, \mathrm{Ca}, \mathrm{Mg}, \mathrm{Zn}$, $\mathrm{Fe}$ and $\mathrm{Cu}$ in the leaves. The base mixture substrate (composed by soil and organic compost) and fertilization with $1 \%$ of cow urine can be indicated to T. grandiflorum plantlets organic production. Index terms: Nutrient content, Gas exchange, Growth rate, Organic fertilization; Theobroma grandiflorum.
\end{abstract}

\section{Substrato para mudas de cupuaçuzeiro e influência da urina de vaca como biofertilizante}

Corresponding author: egross@uesc.br

Received: December 12, 2020 Accepted: June 18, 2021

Copyright: All the contents of this journal, except where otherwise noted, is licensed under a Creative Commons Attribution License.
Resumo - A utilização de resíduos orgânicos como componentes de substrato para a produção de mudas de frutíferas provê materiais alternativos de fácil disponibilidade e de baixo custo. O objetivo deste trabalho foi avaliar o efeito do substrato e da biofertilização com urina de vaca no crescimento do cupuaçuzeiro (Theobroma grandiflorum), em sistema de produção orgânico. Foi conduzido um experimento fatorial em delineamento inteiramente casualizado, com 12 repetições, incluindo quatro tipos de substrato (mistura-base; mistura-base + fibra de coco; mistura-base + casca de cacau e mistura-base + areia), com ou sem aplicação de biofertilizante, totalizando 96 unidades experimentais. O substrato e o biofertilizante influenciaram as trocas gasosas e o crescimento das plantas de $T$. grandiflorum. A interação entre os dois fatores afetou significativamente a matéria seca, a taxa de crescimento relativo, a taxa fotossintética líquida e o conteúdo de $\mathrm{P}, \mathrm{K}$ e Mn nas folhas. De forma independente, os fatores substrato e aplicação de urina de vaca influenciaram o índice de clorofila, a área foliar, o diâmetro e a altura das plantas de cupuaçu e os teores de $\mathrm{N}, \mathrm{Ca}, \mathrm{Mg}, \mathrm{Zn}, \mathrm{Fe}$ e $\mathrm{Cu}$ na parte aérea. A mistura-base do substrato (formada por solo e composto orgânico) e a fertilização com $1 \%$ de urina de vaca podem ser indicadas para a produção orgânica de mudas de T. grandiflorum.

Termos para indexação: Conteúdo de nutrientes, Trocas gasosas foliares, Taxa de crescimento, Fertilização orgânica; Theobroma grandiflorum.

${ }^{1} \mathrm{PhD}$ student, Graduate Program in Crop Production, Universidade Estadual de Santa Cruz, Ilhéus-BA, Brazil. E-mail: anapaulaifbaiano@ hotmail.com (ORCID 0000-0002-0593-4211)

${ }^{2} \mathrm{PhD}$ in Crop Science, Comissão Executiva do Plano da Lavoura Cacaueira, Ilhéus-BA, Brazil. E-mail: marrocos@uesc.br ${ }^{\text {(ORCID } 0000-0003-}$ 3574-5152)

${ }^{3}$ PhD in Plant Physiology, Universidade Estadual de Santa Cruz, Ilhéus-BA, Brazil. E-mail: msmielke@uesc.br (0RCID 0000-0001-6930-2902)

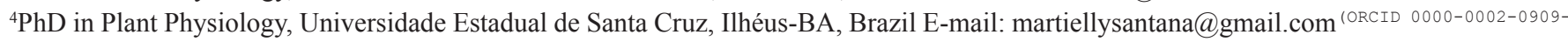
2664)

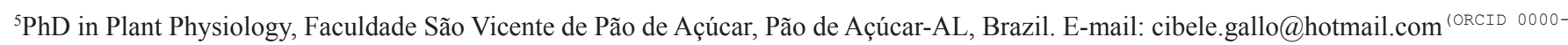
0002-0157-8504)

${ }^{6} \mathrm{PhD}$ in Plant Sciences, Universidade Estadual de Santa Cruz, Ilhéus-BA, Brazil E-mail: egross@uesc.br(ORCID 0000-0002-1057-0432) 


\section{Introduction}

Agroforestry systems for commercial and homegrown orchards have been adopted to increase the value of products from the Atlantic Forest and the Amazon, especially in the north and south of the state of Roraima and in the south and extreme south of Bahia (Marques et al., 2016). As an example, plantations of the cupuaçu tree (Theobroma grandiflorum) can be cited. The cupuaçu is a perennial fruit tree with spontaneous development in the western Amazon forests and currently distributed in all Brazilian states (CALZAVARA, 1987), and it is considered an important source of income and employment for producers in these regions (LIMAPRIMO et al., 2018).

The cultivation system generally used for cupuaçu tree plantations is below productive potential, mainly due to inadequate management, beginning with the production of plantlets with low agronomic quality (LIMA-PRIMO et al., 2018). This production is influenced by internal factors, such as seed quality, and external factors, such as substrate and the fertilizer used (FERREIRA et al., 2009).

The substrate, which is made up of physical, chemical and biological fractions, is the environment where the roots grow and develop (KÄMPF, 2000). It consists of mineral and organic particles, containing pores occupied by water and/or air, influencing root absorption capacity, and, consequently, plantlets development (SUGUINO et al., 2011). The greater the diversity of materials used in the production of the substrate, the greater the available nutritional diversity for plant growth (VICENTINI et al., 2009), which enables plants to achieve their productive potential (SODRÉ et al., 2009). It is possible to obtain such conditions with the addition of conditioners to the substrate, which can be acquired from organic residues from agricultural industries (ARAÚJO NETO et al., 2015).

Regionally available agro-industrial wastes can be used as conditioners, as they have lower costs and contribute to reducing the environmental impact (TERRA et al., 2017). In this context, in the south of Bahia, two organic agro-industrial residues can be found with potential for use in substrates. These are the shell of the cocoa fruit, which is generated on farms through the harvest and separation of cocoa beans; and coconut shells, generated in the trade and industry of coconut water and coconut by-products.

The treatment and process of composting cocoa fruit shells transform these residues into an organic biofertilizer with low pollution potential (DOMÍNGUEZ et al., 2010) and high influence on the degree of colonization of arbuscular mycorrhizal fungi (GOMES JÚNIOR et al., 2018). Coconut shell fiber is generated by the agricultural industry of coconut water packing. The coconut shell represents $80 \%$ to $85 \%$ of the gross weight of the fruit and around $70 \%$ of all the waste generated on beaches along the entire Brazilian coast (Rosa et al., 2001). However, after triple washing (MATTOS et al., 2017), the shell presents favorable characteristics as a substrate conditioner for cultivated plants mainly for its physical structure, providing adequate aeration and water retention (KRAUSE et al., 2017). Associated with the use of these residues, washed sand can also be included in the substrate, as it has the advantage of low cost, chemical inactivity, structural stability and ease of cleaning and disinfection (Sodré, 2007). In addition, the use of washed sand as a substrate conditioner improves porosity, water drainage (BITENCOURT, et al., 2010) and aeration to the roots (TERRA et al., 2017).

Like the substrate, biofertilization is considered essential for the growth of organic plantlets. It is possible to use by-products of cattle rearing, such as cow urine, which is described as a disinfectant (Mohanty et al., 2014) with phytosanitary value, as it increases the resistance of plantlets to pests and diseases (BRASIL, 2018). Cow urine is rich in mineral elements, providing nutrients and other beneficial substances to plants at low cost to the farmers (Oliveira et al., 2010), and the efficiency of its use as biofertilizer influencing crops productivity has been proved (NÁPOLES et al., 2017; FREIRE et al., 2019).

Adequate management of organic plantlets provides better conditions for initial field growth, contributing to the phytosanitary aspects and reducing crop mortality (FERREIRA et al., 2009), facilitating medium and long-term crop handling (Oliveira, 2006). Thus, this study verified the impact of the substrate composition and cow urine application on the growth of cupuaçu plantlets analyzing their physiological, morphological and nutritional characteristics.

\section{Material and methods}

\section{Experimental conditions}

The experiment was conducted at the nursery of Instituto Floresta Viva (IFV), situated in the Serra Grande district, in municipality of Uruçuca, Bahia, Brazil (geographical coordinates -14,463020/-39,045151, Datum SIRGAS 2000), between March and September 2019. The nursery where the experiment was installed is covered with black shading screens that allow $50 \%$ of the available solar radiation to pass when there is full sunlight. According to Köppen-Geiger, the experiment region has Af type climate, which is hot and humid, with a mean temperature of $24.4^{\circ} \mathrm{C}$, without a defined dry season, and mean monthly rainfall of $50 \mathrm{~mm}$ to $100 \mathrm{~mm}$, which can reach up to $150 \mathrm{~mm}$. These rainfall rates are typical of tropical forests (CLIMATE-DATA.ORG, 2020), so the plantlets were irrigated when there was no rain for three consecutive days, according to the nursery schedule. 
Fruits from the matrices for plantlets production were obtained from the Instituto Federal Baiano (IF Baiano) of Uruçuca Campus. Following the determinations of MAPA normative instructions $n^{\circ}$ $38 / 2011$, which establishes technical regulations for plantlets production in organic production systems, fruits were selected by size and shape, and they were manually pulped. The seeds were washed in running water and dried in the shade on paper towels for $24 \mathrm{~h}$. To minimize the influence of genetic variability, 710 seeds were selected by size, shape, and weight ( $4.5 \mathrm{~g}$ each). They were then put to germinate for 30 days in a seedbed with washed sterilized sand.

The seedlings with similar development characteristics were selected for the experiment, namely those with $13 \mathrm{~cm}$ between the root-stem transition zone and the sprouting end of the main branch of the plantlets, $20 \mathrm{~mm}$ stem diameter and two expanded leaves. Pricking out was performed onto plastic bags $33 \mathrm{~cm}$ high and 21 cm wide.
Base mixture (BM) substrate was produced with soil (75\%) and organic compost (25\%) (Table 1), according to the methodology of Araújo Neto et al., (2015) for the cultivation of cupuaçu trees. The soil was obtained from the IFV area, where the organic compost was previously produced with cattle and chicken manures, at a proportion of $1: 1$, after 240 days of composting process. The organic compost was sieved (4 mm opening) before use. The coconut shell fiber was acquired from a coconut water factory in the municipality of Una (Bahia State). The cocoa shell compost came from Comissão Executiva do Plano da Lavoura Cacaueira (CEPLAC) area localized at Ilhéus municipality, and the washed sand was acquired from a building supplies store in the municipality of Uruçuca, (Bahia State). The chemical characteristics of the materials used in the composition of the substrates are shown in Table 1. The other three substrates were prepared using $70 \%$ of BM and $30 \%$ of each material: coconut fiber (BM-CF), cocoa shell (BM$\mathrm{CS})$ and sand (BM-S).

Table 1. Physical and chemical attributes of the substrate components before preparing the mixtures for treatments.

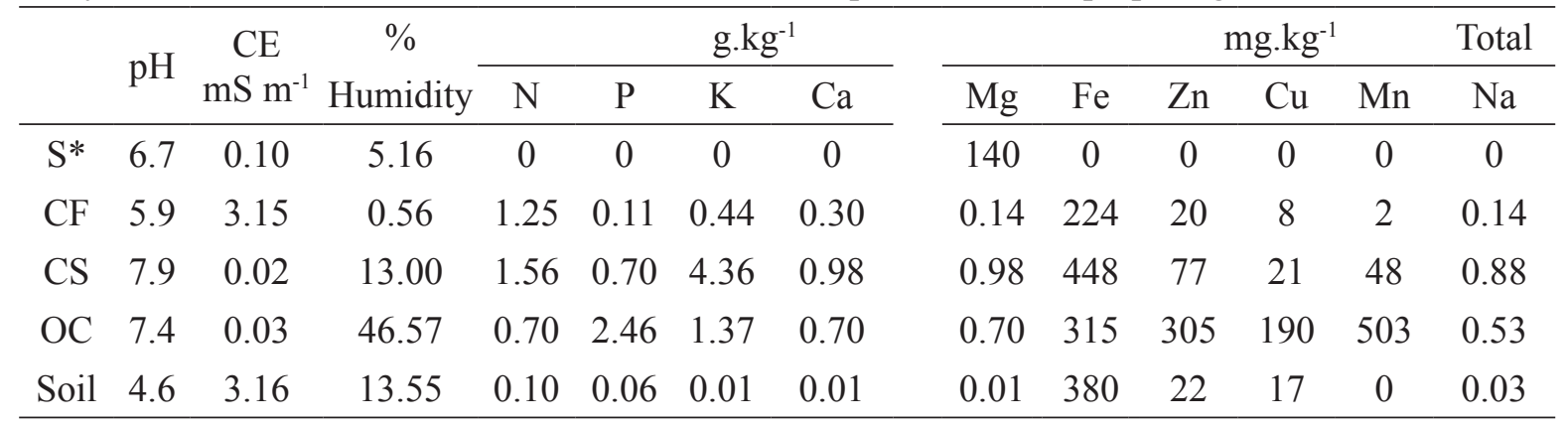

$* \mathrm{~S}=$ sand; $\mathrm{CS}=$ cocoa shell; $\mathrm{OC}=$ organic compost, $\mathrm{CF}=$ coconut fiber.

The cow urine used in the experiment was collected from cows in the dairy herd of IF Baiano and was diluted to $1 \%$ in collected rainwater. The solution was applied (approximately $100 \mathrm{ml}$ per plant) to the cupuaçu at the morning period, using a backpack sprayer, every 15 days, for four months, following the methodology adopted by IFV nursery to the production of native tree species. Cupuaçu plantlets without biofertilizer application received $100 \mathrm{~mL}$ of collected rainwater at each application date.

The experimental design was completely randomized with 12 replications (plantlets) in a $4 \times 2$ factorial scheme, the four different substrates (BM, BMCF, BM-CS and BM-S) with and without cow urine application totalizing 96 sample units.

\section{Growth analysis}

At the beginning of the experiment, at the moment of plantlets pricking out onto plastic bags, ten seedlings were sampled for initial time (T1) evaluations of shoot height $(\mathrm{H})$, diameter of the root-stem transition zone
(D), number of leaves, leaf area (LA), total dry weight (TDW), dry weight of the roots (DWR), stem (DWS), leaves (DWL) and shoot (DWAP), followed by chemical analysis of the leaves were carried out. The LA of each seedling was determined using an LI-3100C, Li-Cor area meter (Li-Cor, inc. Lincoln, Nebraska, USA). To obtain the dry weights (DWR, DWS and DWL), ten seedlings were selected and taken to the Plant Physiology Laboratory of UESC, where they were washed, separated into root, stem, and leaves, and individually placed in identified paper bags and dried in a forced air oven at $65^{\circ} \mathrm{C}$ until reaching constant weight. Total dry weight was calculated from the values for DWR, DWS and DWL $($ TDW=DWR+DWS+DWL).

The cupuaçu tree plantlets grew in the nursery for 152 days, and every 30 days, measurements were taken of shoot height (measured with a ruler), diameter at the root-stem transition zone (using a digital vernier caliper, taking two perpendicular measurements between each other at the base of the root-stem transition zone), number of leaves, and chlorophyll content estimate using a chlorophyll meter ClorofiLog (Falker, Porto Alegre, Brazil). 
At the end of the experiment, all the plants were collected to obtain dry weight data, following the same methodology used for the plants at $\mathrm{T} 1$. The dry weight and leaf area data were then used to calculate: leaf area ratio: $\mathrm{LAR}=\mathrm{LA} / \mathrm{TDW}$; leaf weight ratio: $\mathrm{LWR}=\mathrm{DWL} /$ TDW; root weight ratio: $\mathrm{RWR}=\mathrm{DWR} / \mathrm{TDW}$, relative growth rate: $\mathrm{RGR}=\ln$ TDW2-lnTDW1/T2-T1), and liquid assimilation rate: $\mathrm{LQAR}=((\mathrm{TDW} 2-\mathrm{TDW} 1) /(\mathrm{T} 2-$ T1))x((lnLA2-lnLA1)/(LA2-LA1))), following Hunt (2016) procedures.

\section{Leaf gas exchange measures}

The net photosynthetic rate $(A)$, stomatal conductance $(g s)$ and the relationship between internal $\mathrm{CO}_{2}$ concentration and that of the environment $(\mathrm{Ci} / \mathrm{Ce})$ were measured using an infrared gas analyzer, Li-6400 model (Li-Cor, USA) equipped with an artificial light source (6500-02B RedBlue). Measurements were carried out on completely expanded mature leaves, between 8 am and 11 am, under artificial photosynthetically active radiation (PAR) of $1,000 \mu \mathrm{mol}$ photons $\mathrm{m}^{-2} \mathrm{~s}^{-1}$ at leaf level and around $390 \pm 10 \mu \mathrm{mol} \mathrm{CO} \mathrm{mol}^{-1}$. During the measurements, the temperature of the block was maintained at $28 \pm 1{ }^{\circ} \mathrm{C}$ and relative humidity at $65 \% \pm 5$ in all the plantlets.

\section{Nutrient analysis of the leaves}

At the end of the growth period, the dried leaves of the plants from each treatment were sent to the laboratory of the Cocoa Research Center in CEPLAC for the leaf tissue analysis. The leaves were ground in a ball grinder (Tecnal, TE-3500 model) and a sample from each treatment was used for analysis of the macro and micronutrient content. Nitrogen $(\mathrm{N})$ after sulfuric distillation was dosed for titration with $\mathrm{HCl}$. Phosphorus (P) and potassium $(\mathrm{K})$ concentrations were determined in the nitric-perchloric digestion extractor (Silva, 2009). P was determined using molecular absorption spectrophotometry and $\mathrm{K}$ was determined using flame photometry. For the micronutrients, the atomic absorption spectrophotometric method was used. Macro and micronutrient leaf concentration was multiplied by the dry leaf weight to obtain leaf nutrient content.

\section{Statistical analysis}

The obtained data were analyzed using factorial analysis of variance (ANOVA), followed by t-test for the fertilization factor and Tukey's test for the substrate factor, at a $5 \%$ level of significance using the Statistica 8 program.

\section{Results and discussion}

The substrates and the biofertilizer application (cow urine at 1\%) influenced the growth of the cupuaçu plantlets, promoting significant responses in leaf gas exchanges (Table 2 and 3), in growth and in mineral nutrition (Table 2, 3 and 4).

Table 2. Net photosynthetic rate (A), total dry weight (TDW), relative growth rate (RGR), and leaves content of P, K and $\mathrm{Mn}$ of cupuaçu plantlets cultivated on different substrates, fertilized or not with cow urine (1\%) after 152 days of growth.

\begin{tabular}{|c|c|c|c|c|c|}
\hline \multirow{2}{*}{ Variable } & \multirow{2}{*}{ Fertilization } & \multicolumn{4}{|c|}{ Substrates } \\
\hline & & $\mathrm{BM}$ & $\mathrm{BM}-\mathrm{CF}$ & BM-CS & BM-S \\
\hline \multirow{2}{*}{$A\left(\mu \mathrm{mol} \mathrm{m} \mathrm{m}^{-2} \mathrm{~s}^{-1}\right)$} & Without & $3.2 \pm 0.19 \mathrm{bA} *$ & $4.4 \pm 0.15 \pm \mathrm{aB}$ & $4.4 \pm 0.34 \mathrm{aA}$ & $5.3 \pm 0.09 \mathrm{aA}$ \\
\hline & With & $3.6 \pm 0.09 \mathrm{cA}$ & $5.9 \pm 0.11 \mathrm{aA}$ & $4.5 \pm 0.10 \mathrm{bA}$ & $2.9 \pm 0.17 \mathrm{cB}$ \\
\hline \multirow{2}{*}{ TDW (g) } & Without & $9.6 \pm 0.17 \mathrm{aB}$ & $8.1 \pm 0.24 \mathrm{abB}$ & $7.2 \pm 0.47 \mathrm{bA}$ & $7.7 \pm 0.41 \mathrm{bB}$ \\
\hline & With & $14.2 \pm 0.59 \mathrm{aA}$ & $9.4 \pm 0.34 \mathrm{bA}$ & $7.7 \pm 0.36 \mathrm{cA}$ & $9.5 \pm 0.17 \mathrm{bA}$ \\
\hline \multirow{2}{*}{ RGR (mg g ${ }^{-1}$ day $\left.^{-1}\right)$} & Without & $17.6 \pm 0.12 \mathrm{aB}$ & $16.5 \pm 0.19 \mathrm{abB}$ & $15.6 \pm 0.46 \mathrm{bA}$ & $16.1 \pm 0.36 \mathrm{bB}$ \\
\hline & With & $20.1 \pm 0.28 \mathrm{aA}$ & $17.5 \pm 0.23 \mathrm{bA}$ & $16.1 \pm 0.30 \mathrm{cA}$ & $17.4 \pm 0.12 \mathrm{bA}$ \\
\hline \multirow{2}{*}{$\mathrm{P}(\mathrm{g})$} & Without & $9.1 \pm \mathrm{aB}$ & $8.3 \pm b B$ & $10.8 \pm \mathrm{aA}$ & $8.4 \pm \mathrm{aA}$ \\
\hline & With & $16.8 \pm \mathrm{aA}$ & $12.6 \pm \mathrm{bA}$ & $12.2 \pm \mathrm{bA}$ & $11.3 \pm \mathrm{bA}$ \\
\hline \multirow{2}{*}{$\mathrm{K}(\mathrm{g})$} & Without & $5.5 \pm \mathrm{aA}$ & $4.7 \pm \mathrm{aB}$ & $5.0 \pm \mathrm{aB}$ & $5.4 \pm \mathrm{aA}$ \\
\hline & With & $7.7 \pm \mathrm{aA}$ & $7.2 \pm \mathrm{aA}$ & $8.2 \pm \mathrm{aA}$ & $6.6 \pm \mathrm{aA}$ \\
\hline \multirow{2}{*}{ Mn (mg) } & Without & $51,9 \pm \mathrm{aA}$ & $49,4 \pm \mathrm{aA}$ & $38,8 \pm \mathrm{bA}$ & $65,1 \pm \mathrm{aB}$ \\
\hline & With & $62,4 \pm \mathrm{abA}$ & $75,4 \pm \mathrm{aA}$ & $64,8 \pm \mathrm{aA}$ & $94,5 \pm \mathrm{aA}$ \\
\hline
\end{tabular}

* Mean values \pm standard error. Means followed by the same lower-case letter in the rows and by same upper-case letter in the column do not differ by Tukey's test and t-test at $5 \%$ probability for each variable. $\mathrm{BM}=$ base mixture $(100 \%), \mathrm{BM}-\mathrm{S}=$ base mixture + sand; $\mathrm{BM}-\mathrm{CF}=$ base mixture + coconut fiber; BM-CS = base mixture + cocoa shell. 
Table 3. Relationship of internal and environmental concentration of $\mathrm{CO}_{2}(\mathrm{Ci} / \mathrm{Ca})$, chlorophyll index $(\mathrm{CI})$, leaf area (LA), diameter (D), height $(\mathrm{H})$, liquid assimilation rate (LQAR), leaf area ratio (LAR), and leaves content of nitrogen $(\mathrm{N})$, calcium $(\mathrm{Ca})$ and zinc $(\mathrm{Zn})$ of cupuaçu plantlets cultivated on different substrates after 152 days of growth.

\begin{tabular}{lcccc}
\hline \multirow{2}{*}{ Variable } & \multicolumn{4}{c}{ Substrate $(\mathrm{S})$} \\
\cline { 2 - 5 } & $\mathrm{BM}$ & BM-CF & BM-CS & BM-S \\
\hline $\mathrm{Ci} / \mathrm{Ca}$ & $1.0 \pm 0.64 \mathrm{~b}^{*}$ & $1.5 \pm 0.71 \mathrm{a}$ & $1.2 \pm 0.66 \mathrm{ab}$ & $1.2 \pm 0.71 \mathrm{ab}$ \\
$\mathrm{CI}$ & $20.19 \pm 0.43 \mathrm{ab}$ & $20.62 \pm 0.50 \mathrm{a}$ & $18.73 \pm 0.52 \mathrm{~b}$ & $20.17 \pm 0.56 \mathrm{ab}$ \\
$\mathrm{LA}\left(\mathrm{cm}^{2}\right)$ & $748.5 \pm 46.4 \mathrm{a}$ & $585.7 \pm 36.1 \mathrm{~b}$ & $598.0 \pm 51.0 \mathrm{~b}$ & $643.0 \pm 47.1 \mathrm{ab}$ \\
$\mathrm{D}(\mathrm{mm})$ & $7.2 \pm 0.19 \mathrm{a}$ & $6.4 \pm 0.17 \mathrm{~b}$ & $6.4 \pm 0.24 \mathrm{~b}$ & $6.4 \pm 0.19 \mathrm{~b}$ \\
$\mathrm{H}(\mathrm{cm})$ & $36.1 \pm 1.53 \mathrm{a}$ & $30.7 \pm 1.25 \mathrm{~b}$ & $25.5 \pm 1.14 \mathrm{~b}$ & $28.9 \pm 1.58 \mathrm{ab}$ \\
$\mathrm{LQAR}\left(\mathrm{mg} \mathrm{cm}^{-1} \mathrm{day}^{-1}\right)$ & $0.23 \pm 0.01 \mathrm{a}$ & $0.20 \pm 0.01 \mathrm{~b}$ & $0.17 \pm 0.01 \mathrm{~b}$ & $0.18 \pm 0.01 \mathrm{ab}$ \\
$\mathrm{LAR}\left(\mathrm{dm}^{2} \mathrm{~g}^{-1}\right)$ & $80.3 \pm 6.21 \mathrm{a}$ & $68.1 \pm 4.31 \mathrm{ab}$ & $65.7 \pm 4.13 \mathrm{~b}$ & $74.5 \pm 4.08 \mathrm{ab}$ \\
$\mathrm{N}(\mathrm{g})$ & $58.3 \pm 3.58 \mathrm{a}$ & $58.6 \pm \mathrm{a}$ & $56.0 \pm \mathrm{ab}$ & $49.0 \pm 2.70 \mathrm{~b}$ \\
$\mathrm{Ca}(\mathrm{g})$ & $59.3 \pm 5.05 \mathrm{a}$ & $47.0 \pm \mathrm{ab}$ & $36.8 \pm \mathrm{b}$ & $42.1 \pm 4.30 \mathrm{~b}$ \\
$\mathrm{Zn}(\mathrm{mg})$ & $280.3 \pm 29.98 \mathrm{a}$ & $224.8 \pm \mathrm{ab}$ & $185.4 \pm \mathrm{b}$ & $161.3 \pm 12.64 \mathrm{~b}$ \\
\hline
\end{tabular}

* Mean values \pm standard error. Means followed by the same letter in the rows do not differ by Tukey's test at $5 \%$ probability. BM $=$ base mixture $(100 \%), \mathrm{BM}-\mathrm{S}=$ base mixture + sand; BM-CF $=$ base mixture + coconut fiber; BM-CS $=$ base mixture + cocoa shell.

Table 4. Leaf area ratio (LAR), liquid assimilation rate (LQAR), leaf weight ratio (LWR), root weight ratio (RWR), height $(\mathrm{H})$, diameter (D), and leaves content of $\mathrm{N}, \mathrm{Ca}, \mathrm{Mg}, \mathrm{Fe}, \mathrm{Cu}$ and $\mathrm{Zn}$ of cupuaçu plantlets fertilized or not with cow urine (1\%) after 152 days of growth.

\begin{tabular}{lcc}
\hline Variable & Without biofertilizer & With biofertilizer \\
\hline LAR $\left(\mathrm{dm}^{2} \mathrm{~g}^{-1}\right)$ & $78.3 \pm 5.89 \mathrm{a}^{*}$ & $65.6 \pm 3.48 \mathrm{~b}$ \\
LQAR $\left(\mathrm{mg} \mathrm{cm}^{-1} \mathrm{day}^{-1}\right)$ & $0.18 \pm 0.01 \mathrm{~b}$ & $0.21 \pm 0.01 \mathrm{a}$ \\
LWR $\left(\mathrm{dm}^{2} \mathrm{~g}^{-1}\right)$ & $0.41 \pm 0.02 \mathrm{a}$ & $0.35 \pm 0.02 \mathrm{~b}$ \\
RWR $\left(\mathrm{dm}^{2} \mathrm{~g}^{-1}\right)$ & $0.3 \pm 0.02 \mathrm{~b}$ & $0.4 \pm 0.02 \mathrm{a}$ \\
$\mathrm{H}(\mathrm{cm})$ & $28.9 \pm 1.23 \mathrm{~b}$ & $31.7 \pm 1.52 \mathrm{a}$ \\
$\mathrm{D}(\mathrm{mm})$ & $6.3 \pm 0.19 \mathrm{~b}$ & $6.9 \pm 0.20 \mathrm{a}$ \\
$\mathrm{N}(\mathrm{g})$ & $44.3 \pm 2.19 \mathrm{~b}$ & $61.7 \pm 1.68 \mathrm{a}$ \\
$\mathrm{Ca}(\mathrm{g})$ & $33.6 \pm 3.10 \mathrm{~b}$ & $58.9 \pm 3.24 \mathrm{a}$ \\
$\mathrm{Mg}(\mathrm{g})$ & $6.4 \pm 0.39 \mathrm{~b}$ & $9.2 \pm 0.42 \mathrm{a}$ \\
$\mathrm{Fe}(\mathrm{mg})$ & $1041.1 \pm 61.77 \mathrm{~b}$ & $1572.5 \pm 67.69 \mathrm{a}$ \\
$\mathrm{Cu}(\mathrm{mg})$ & $17.4 \pm 1.79 \mathrm{~b}$ & $26.8 \pm 3.2 \mathrm{a}$ \\
$\mathrm{Zn}(\mathrm{mg})$ & $173.0 \pm 15.8 \mathrm{~b}$ & $252.9 \pm 23.8 \mathrm{a}$ \\
\hline
\end{tabular}

* Mean values \pm standard error. Means followed by the same letter in the rows do not differ between each other by t-test at $5 \%$ probability. BM $=$ base mixture $(100 \%), \mathrm{BM}-\mathrm{S}=$ base mixture + sand; $\mathrm{BM}-\mathrm{CF}=$ base mixture + coconut fiber; $\mathrm{BM}-\mathrm{CS}=$ base mixture + cocoa shell.

Biofertilization had an impact on growth and survival of the plantlets after the 152 days of the experiment. This can be demonstrated by the death of some plants in the treatments without cow urine application. In total, the death of 10 plantlets was observed, six being in the BMCS substrate. The high mortality observed in this substrate without biofertilization may be explained by the high $\mathrm{pH}$ (7.9) of the cocoa shell used in its composition, thus compromising the quality and resistance of the plantlets to the attack of pathogens (Table 1). Similar results were reported by Araújo Neto et al., (2015) in cupuaçu plantlets, using a substrate containing Ceiba pentandra (L.) Gaertn. residue, which presented $\mathrm{pH} 8.1$. 
No deaths were observed in the biofertilized treatments, reinforcing the importance of cow urine as an organic fertilizer and biopesticide since it promoted an increase in nutrient availability and resistance to the attack of pathogens on the plants. This finding is reinforced by the trophobiosis theory (COSTA et al., 2015) and corroborated by Freire et al., (2019). The nutritional status was detected by chemically analysis of cupuaçu plantlets leaves, which presented a significant increase in $\mathrm{N}(10 \%), \mathrm{Ca}(75.5 \%)$, $\mathrm{Zn}(46 \%), \mathrm{Mg}(44 \%), \mathrm{Fe}(51 \%)$ and $\mathrm{Cu}(54 \%)$ when biofertilized with cow urine (Table 4). Freire et al., (2019) when analyzing chemically cow urine, obtained means of 4.20 g. $\mathrm{kg}^{-1}$ of N, 0.63 g.k $\mathrm{kg}^{-1}$ of Ca; $4.00 \mathrm{mg} \cdot \mathrm{kg}^{-1}$ of $\mathrm{Zn}$; $0.26 \mathrm{~g} \cdot \mathrm{kg}^{-1}$ of Mg; $21.00 \mathrm{mg} \cdot \mathrm{kg}^{-1}$ of Fe and $1.00 \mathrm{mg} \cdot \mathrm{kg}^{-1}$ of $\mathrm{Cu}$, which may justify the results for nutritional status of cupuaçu plantlets. Cow urine as a liquid fertilizer to the plants has been encouraged in organic production system (LANGMEIER et al., 2002), considering that is a product with high viability of use as a nutritional source (FREIRE at al., 2019).

For the cupuaçu, the cow urine also improved morphophysiological conditions, as observed in the net photosynthetic rate, in growth (Table 2 and 4 ) and in the allocation of biomass to the root system (Table 4). Biofertilized plantlets presented increases of $19 \%$ and $35 \%$ for LQAR and RWR, respectively, revealing the influence of cow urine on increased total dry weight in function of leaf area (LQAR), with greater allocation of biomass to the root system, which guarantees plantlets resistance to environmental stress and increases the survival rate in the field (GOMES JÚNIOR et al., 2018). The indirect effect on plantlets growth through rooting was also observed by Gadelha et al., (2009) in pineapple plantlets.

Similarly, the application of biofertilizer increased $10 \%$ the height $(\mathrm{H})$ and diameter $(\mathrm{D})$ of the cupuaçu plantlets. These significant results for these variables were also observed by Véras et al. (2014) when studied the use of cow urine at $1 \%$ and $5 \%$ as biofertilizer in Tamarindus indica. The $\mathrm{H}$ and $\mathrm{D}$ values observed in cupuaçu plantlets are even higher (115\% and $150 \%$, respectively) than those found by Nascimento et al. (2017) when using biofertilizers produced with cow manure and organic material on cupuaçu, after seedling emergence, with one application per week for 72 days.

The beneficial influence of coconut fiber as a substrate conditioner was shown in the net photosynthetic rate $(A)$ of biofertilized plantlets, with an increase of up to $104 \%$ when compared with the other treatments, and the lowest value was observed in plantlets cultivated in BM-S substrate (Table 2). This result may be associated with the $10 \%$ increase observed in the chlorophyll index (CI), which, in turn, was influenced by the greater increase in $\mathrm{N}(20 \%)$ found in the BM-CF substrate (Table $3)$. This fact is justified, as $\mathrm{N}$ is present in the structure of chlorophyll, which is an important pigment in the photochemical stage of photosynthesis (CHAPMAN et al., 1997), and its presence in the leaf indicates foliar activity, resulting in an increase in the photosynthesis rate, in the metabolism, in the formation of structural components and in the allocation of biomass (Wright et al., 2000), contributing to the development of seedlings (KRAUSE et al., 2017). Similar results in the photosynthetic rate were observed by Silva et al., (2009) in Hancornia speciosa, when evaluating substrates with different proportions of compost with cow manure.

Although significant differences in stomatal conductance (gs) were not found, the higher value of $A$ in BM-CF may also be related to the greater availability of $\mathrm{CO}_{2}$ in the intercellular spaces due to the higher $\mathrm{Ci}$ / Ce ratio $(50 \%)$ found in this substrate (Table 3 ). Through the $\mathrm{Ci} / \mathrm{Ce}$ ratio it is possible to verify the efficiency or not in the carbon fixation reactions, being considered an appropriate indicator for the stomatal limitation of photosynthesis, responsible for the changes in stomatal opening and resistance to the influx of $\mathrm{CO}_{2}$ (GUERRA et al., 2017), which, in this case, favored the biochemical stage of photosynthesis.

The effect of the combination of the substrate type and the biofertilizer were observed for TDW and RGR in cupuaçu plantlets, demonstrating significance in the BM substrate and in biofertilization, with an increase of up to $98 \%$ and $29 \%$, respectively, when compared to the other treatments, which did not differ between each other (Table 2). Considering that the nutritional conditions of the plant influence the increase in the RGR value (LAMBERS et al., 1992), and that RGR is related to the increase in biomass from pre-existing biomass (HUNT, 2016), the results observed in the present study are justified by the increase in mineral nutrient absorption in these treatments, resulting in physiological responses in the plantlets, with greater biomass production (TDW), which, in turn, influenced the increase in RGR (ZULFIQAR et al., 2019).

Furthermore, the combination between the factors showed significant results for $\mathrm{P}$ and $\mathrm{K}$ content in the leaves of cupuaçu plantlets. The highest values were observed in the treatments with biofertilization, reinforcing the nutritional importance of cow urine for the plantlets. Regarding the substrate, however, the best results were in $\mathrm{BM}$ for $\mathrm{P}$ and BM-CS for $\mathrm{K}$, compared with the other treatments, which did not present differences between each other (Table 2). This result was attributed to the higher content of these ions observed in the respective components of these substrates. BM substrate contains $7.5 \%$ more organic compost than the other substrates, with a $P$ content 3.5 times greater than the cocoa shell compost used in the BM-CS substrate, which, in turn, presented $\mathrm{K}$ content 3.2 times greater than organic compost. The $\mathrm{P}$ and $\mathrm{K}$ values of the coconut shell fiber and sand conditioners were up to 10 times lower when compared to the organic compost and the cocoa shell (Table 1). 
The high $\mathrm{K}$ value found in the composition of the BM-CS substrate possibly provoked luxury consumption of this element by the cupuaçu plantlets cultivated in this substrate, causing an antagonistic effect in $\mathrm{K} / \mathrm{Ca}$ (MENARD et al., 1962), reducing the leaf content of $\mathrm{Ca}$ through competitive inhibition of absorption (TAIZ et al., 2017). This can be confirmed by the lower value for Ca observed in BM-CS (36.8 g per leaves). A similar result was reported by Sodré et al., (2012) in Theobroma cacao plantlets, and by Souza et al., (2002) in Ananas comosus plantlets, when analyzing the effect of potassium fertilization. This is because, potassium plays a crucial role in several physiological processes, acting on the regulation of stomatal opening and limiting water loss (CAVALCANTE et al., 2018).

When analyzing the results obtained for leaf nutrient content in cupuaçu plantlets as a set, the best responses were observed in biofertilized plantlets grown in BM substrate. When comparing these values (Table 2, 3 and 4) with those presented by Frazão et al. (2006), when they characterized the visual symptoms of macronutrient deficiency in cupuaçu plantlets, and, by Almeida et al., (2021), when evaluating the omission of nutrients in the development and mineral composition of young cupuaçuzeiro plants, it can be stated that the use of cow urine as biofertilizer and BM substrate enables the maintenance of nutritional values of the shoot of the plantlets, above the critical range for the presentation of visual symptoms of deficiencies.

The growth variables analyzed in the cupuaçu plantlets with different responses to type of substrate were H, D, LA, LQAR and LAR (Table 3). All of these variables obtained higher values in BM substrate, which demonstrates the importance of the quantity of organic compost $(30 \%)$ used in the preparation of the substrate, without the addition of conditioners. Studies carried out by other authors demonstrate that organic composts in substrates significantly affect plant growth, as in the example of research carried out by Araújo et al., (2013) in Carica papaya L. plantlets, and by Araújo Neto et al., (2015) and Santos et al., (2014) when testing organic compost in substrate for the growth of cupuaçu plantlets.

The $\mathrm{H}$ and $\mathrm{D}$ variables contributed to the evaluation of cupuaçu plantlets quality, which also increases the estimate for survival in the field (GOMES et al., 2002). Plantlets cultivated in BM substrate show an increase of up to $41.5 \%$ and $12 \%$, respectively, in comparison to the other treatments, which did not differ between each other (Table 3). After 152 days of treatment, the plantlets reached a height of $36.1 \mathrm{~cm}$ and a diameter of $7.2 \mathrm{~mm}$ and were ready for planting in the field (LIMA-PRIMO, 2018).
The highest LA increase was observed in BM substrate, which was around $27.8 \%$ higher than the other treatments, which did not differ between each other. LA represents the raw material for photosynthesis and, as such, is of great importance in the evaluation of plant growth (PEIXOTO et al., 2011), which, in turn, is related to LQAR, a variable that reflects the capacity of the plant to increase its phytomass in function of the assimilatory surface, indicating the efficiency of the plant in the production of dry material (LUCCHESI, 1984). This also explains the higher value of this variable in BM substrate (35\%), when compared to the other substrates, which did not show a difference between each other.

LAR is a growth characteristic that represents the size of the assimilatory surface in relation to total dry biomass. As a variable considered to be a parameter that expresses the useful LA for photosynthesis (HUNT, 2016), in this study, a higher value was also observed $(22.3 \%)$ in BM substrate, when compared to the other substrates, which did not show a difference between each other.

\section{Conclusion}

Different substrate composition and the use of $1 \%$ cow urine as a biofertilizer influenced the development of cupuaçu plantlets. Biofertilization contributed to the survival and growth of plants, improving nutritional and morphophysiological conditions.

The coconut fiber as a conditioner substrate influenced leaf gas exchange, however, among the tested substrates, the most suitable to produce cupuaçu plantlets with higher growth, nutritional increasing and improvement in morphophysiological conditions was the mixture base composed by soil and organic compost. On the other hand, the use of cocoa shell as part of substrate should be careful considered for cupuaçu plantlets production.

\section{Acknowledgements}

We thanks to IFBaiano and UESC for financial support; CEPLAC and the Instituto Floresta Viva for technical support. The present study was carried out also with the support of the Coordination for the Improvement of Higher Education Personnel - Brazil (CAPES). Marcelo S. Mielke would like to thanks to CNPq for the research grant (305477/2018-8). 


\section{References}

ALMEIDA, G.M.; VIÉGAS, I.J.M.; ALVES, R.M.; SILVA, H.B.; SILVA, A.O.; SILVA, D.A.S. Evaluation of the omission of nutrientes in the mineral development and composition of Young cupuaçuzeiro plants (Theobroma grandiflorum (Willd. Ex Spreng.) Schum) progeny 61. Research, Society and Development, Itabira, v.10, n.1, 2021.

ARAÚJO NETO, S.E.; FREDNBERG, N.T.N.; MINOSSO, S.C.C.; NOVELLI, D.S.; ANDRADE Neto, R.C. Condicionadores de substrato para produção orgânica de mudas de cupuaçu. Revista Brasileira de Fruticultura, Jaboticabal, v.37, n.4, p.1083-1088, 2015.

ARAÚJO, A.C.; ARAÚJO, A.C.; DANTAS, M.K.L.; PEREIRA, W.E.; ALOUFA, M.A.I. Utilização de substratos orgânicos na produção de mudas de mamoeiro Formoso. Revista Brasileira de Agroecologia, Porto Alegre, v.8, n.1, p.210-216, 2013.

BITENCOURT, J.; ZUFFELLATO, R.; KOEHLER, H.S. Estaquia de Ginkgo biloba L. utilizando três substratos. Revista Brasileira de Plantas Medicinais, Botucatu, v.12, n.2, p.135-140, 2010.

BOEMEKE, L.R. A urina de vaca como fertilizante, fortificante e repelente de insetos. Agroecologia e Desenvolvimento Rural Sustentável, Porto Alegre, v.3, n.4, p.41-42, 2002.

BRASIL. Ministério da Agricultura, Pecuária e Abastecimento. Ficha agroecológica, tecnologias apropriadas para agricultura orgânica: urina de vaca na adubação de plantas. Brasília (DF): Coordenação de Agroecologia, 2018. (Fertilidade do Solo e Nutrição de Plantas, 28). Disponível em: www.agricultura.gov.br / desenvolvimento-sustentavel/organicos. Acesso em: 20 fev. 2018.

CALZAVARA, B.B.G. Cupuaçuzeiro. Belém: Embrapa/ Centro de Pesquisa Agropecuária do Trópico, 1987. (Recomendações básicas, 1)

CHAPMAN, S.C; BARRETO, H.J. Using a chlorophyll meter to estimate specific leaf nitrogen of tropical maize during vegetative growth. Agronomy Journal, Madison, v.89, n.4, p.557-562, 1997.
CLIMATE-DATA.ORG. Dados climáticos para cidades mundiais. Disponível em: https:/pt.climate-data.org/ america-do-sul/brasil-114/. Acesso em: 20 abr. 2020.

COSTA, R.M.C.; FREIRE, J.L.O.; MACEDO, L.P.M.; SILVA, F.L.; BORGES, C.H.A. Manejo de culturas e equilíbrio trofobiótico no Perímetro Irrigado Cruzeta, RN. Agropecuária Científica no Semiárido, Campina Grande, v.11, n.4, p.72-86, 2015.

DOMÍNGUEZ, J.; GÓMEZ-BRANDÓN, M. Ciclos de vida de laslombrices de tierra aptas para el vermicompostaje. Acta Zoológica Mexicana, Xalapa, v.26, n.2, p.309-320, 2010.

FERREIRA, M.G.R.; ROCHA, R.B.; GONÇALVES E.P.; ALVES, E.U.; RIBEIRO, G.D. Influência do substrato no crescimento de mudas de cupuaçu (Theobroma grandiflorum Schum.). Acta Scientiarum. Agronomy, Maringá, v.1, n.4, p.677-681, 2009.

FRAZÃO, D.A.C.; VIÉDAS, I.J.M. Cupuaçuzeiro: nutrição, calagem e adubação. Belém: Embrapa, 2006. (Circular Técnico 43)

FREIRE, J.L.O.; SILVA, J.R.; NASCIMENTO, G.S.; SANTOS, F.F.S. Atributos de crescimento e produção de cultivares de alfaces irrigadas com águas Salinas e uso de urina bovina. Agropecuária Ciência no Semiárido, Campina Grande, v.15, n.2, p.124-131, 2019.

GADELHA, R.S.S.; CELESTINO, R.C.A.; CARNEIRO G.M. Urina de vaca. 2009. Disponível em: http:// br.geocities.com/sociedade.al ternativa/urina.html. Acesso em: 29 jan. 2020.

GOMES JÚNIOR, G.A.; PEREIRA, R.A.; SODRÉ, G.A.; SACRAMENTO, C.K.; GROSS, E. Inoculation with arbuscular micorrizhal fungi and organic compost from cocoa shell positively influence the growth and mineral nutrition of soursop plants (Annona muricata L.). Revista Brasileira de Fruticultura, Jaboticabal, v.40, n.5, 2018.

GOMES, J.M.; COUTO, L.; LEITE, H.G.; XAVIER, A.; GARCIA, S.L.R. Parâmetros morfológicos na avaliação da qualidade de mudas de Eucalyptus grandis. Revista Árvore, Viçosa, MG, v.26, n.6, p.655-664, 2002.

GUERRA, A.M.N.M.; COSTA, A.C.M.; TAVARES, P.R.F. Atividade fotossintética e produtividade de alface cultivada sob sombreamento. Revista Agropecuária Técnica, Areia, v.38, n.3, p.125-132, 2017. 
HUNT, R. Growth analysis, individual plants. Encyclopedia of Applied Plant Sciences, Amsterdam, v.8, p.421-429, 2016.

KÄMPF, A.N. Produção comercial de plantas ornamentais. Guaíba: Livraria e Editora Agropecuária, 2000. p.155-158.

LANGMEIER, M.; FROSSARD, E.; KREUZER, M.; MÄDER, P.; DUBOIS, D.; OBERSON, A. Nitrogen fertilizer value of cattle manure applied on soils originating from organic and conventional farming systems. Agronomie, Paris, v.22, n.7/8), p.789-800, 2002.

LAMBERS, H.; POORTER, H. Inherent variation in growth rate between higher plants: a search for physiological causes and ecological consequences. Advances in Ecological Research, San Diego, v.23, p.187-261, 1992.

LIMA-PRIMO, H.E.; ALBUQUERQUE, T.S.C.; ARAÚJO, R.F.; ARAÚJO, R.S.; QUEIROZ, E.S.; GUIMARÃES, P.V.P. Recuperação de pomar de cupuaçuzeiro com histórico de alta infestação da doença vassoura-de-bruxa em Roraima. Tema Gerador 9: Manejo de Agroecossistemas e Agricultura Orgânica. In: CONGRESSO LATINO-AMERICANO, 6., CONGRESSO BRASILEIRO, 10., SEMINÁRIO DO DISTRITO FEDERAL E ENTORNO, 5., 2018, Brasília. Anais [...]. Rio de Janeiro: Associação Brasileira de Agroecologia, 2018.

LUCCHESI, A.A. Utilização prática da análise de crescimento vegetal. Anais da Escola Superior de Agricultura Luiz de Queiroz, Piracicaba, v.41, p.181202, 1984.

MARQUES, J.R.B; MONTEIRO, W.R. Substituição sustentável de eritrina por seringueira em SAF de cacaueiro. Agrotrópica, Ilhéus, v.28, p101-122, 2016.

MATTOS, A.L.A.; ROSA, M.F.; CRISÓSTOMO, L.A.; BEZERRA, F.C.; CORREIA, D.; VERAS, L.G.C. Beneficiamento da casca de coco verde. Brasília (DF): Embrapa-Agroindústria Tropical, 2017. p.38. Disponível em http://www.ceinfo.cnpat.embrapa.br/arquivos/artigo 3830.pdf. Acesso em: 28 mar. 2017.

MENARD, L.N.; MALAVOLTA, E. Estudos sobre alimentação mineral do cafeeiro. VII. Interação entre fósforo e ferro em cafeeiro (Coffea arabica L. var. Caturra KMC) cultivado em solução nutritiva. Anais da Escola Superior de Agricultura Luiz de Queiroz, Piracicaba, v.19, p.23-33, 1962.
MOHANTY, I.; SENAPATI, M.R.; JENA, D.; PALAI, S. Diversified uses of cow urine. Reniew article. Internacional Journal of Pharmacy and Pharmaceutical Sciences, Bhopal, v.6, n.3, p.20-22, 2014.

NÁPOLES, F.A.M.; SOUZA, J.T.A.; OLIVEIRA, S.J.C.; MONTENEGRO, F.T.; AZEVEDO, C.A.V. Utilização de manipueira e urina da vaca como fonte de adubação para a cultura do pinhão manso (Jatropha curcas). Revista em Agronegócio e Meio Ambiente, Maringá, v.10, n.1, p.83-102, 2017.

NASCIMENTO, E.P.; CAMPOS, M.C.C.; ALHO, L.C.; SILVA, D.M.P.; WECKHER, F.C.; MANTOVANELLI, B. C.; CUNHA, J.M. Crescimento das mudas de cupuaçu (Theobroma granidlorum) sob efeito de diferentes combinações de biofertilizante. Revista da Universidade Vale do Rio Verde, Três Corações, v.15, n.2, p.861-870, 2017.

OLIVEIRA, C.J. Produção de mudas: frutíferas e flores tropicais. In: SEMANA DO FAZENDEIRO, 28., 2006. Anais [...]. Uruçuca: EMARC, 2006. v.2, p.40-53.

OLIVEIRA, N.L.C.; PUIATTI, M.; SANTOS, R.H.S.; CECON, P.R.; BHERING, A.S. Efeito da urina de vaca no estado nutricional da alface. Revista Ceres, Viçosa, MG, v.57, n.4, p.506-515, 2010.

PEIXOTO, C.P.; CRUZ, T.V.; PEIXOTO, M.F.S.P. Análise quantitativa do crescimento de plantas: conceitos e prática. Enciclopédia Biosfera, Goiânia, v.7, n.13, p.51-76, 2011.

ROSA, M.F.; ABREU, F.A.P.; FURTADO, A.A.L., BRÍGIDO, A.K.L.; NORÕES, E.R.V. Processo agroindustrial: obtenção de pó de casca de coco verde. Fortaleza: Embrapa Agroindústria Tropical, 2001. (Comunicado Técnico)

SANTOS, V.S.; ALVES, R.M.; MELO, G.F.; FILHO, S.M. Uso de diferentes substratos na produção de mudas de cupuaçuzeiro. Enciclopédia Biosfera, Goiânia, v.10, n.18, p.2941, 2014.

SILVA, E.A.; MARUYAMA, W.I.; OLIVEIRA, A.C.; BARDIVIESSO, D.M. Efeito de diferentes substratos na produção de mudas de mangabeira (Hancornia speciosa).

Revista Brasileira de Fruticultura, Jaboticabal, v.31, n.3, p.925-929, 2009.

SODRÉ, G.A. Substrato e estaquia na produção de mudas de cacaueiro. 2007. Tese (Doutorado em Agronomia) - Faculdade De Ciências Agrárias E Veterinárias, Universidade Estadual Paulista, Jaboticabal, 2007. 
SODRÉ, G.A.; MARROCOS, P.C.L. Manual da produção vegetativa de mudas de cacaueiro. Ilhéus: Editus, 2009. p.46.

SODRÉ, G.A.; VENTURINI, M.T.; RIBEIRO, D.O.; MARROCOS, P.C.L. Extrato da casca do fruto do cacaueiro como fertilizante potássico no crescimento de mudas de cacaueiro. Revista Brasileira de Fruticultura, Jaboticabal, v.34, n.3, p.881-887, 2012.

SOUZA, L. F. da S.; GONÇALVES, N. B.; R. C.; CALDAS, A. G. S.; MEDINA, V. M. Influência da adubação potássica nos teores foliares de nutrientes do abacaxizeiro 'Pérola'. In: CONGRESSO BRASILEIRO DE FRUTICULTURA, 17., 2002, Belém. Anais [...] Belém: SBF; Embrapa, 2002.

SUGUINO, E.; MARTINS, A.N.; MINAMI, K.; NARITA, N.; PERDONÁ, M.J. Efeito da porosidade do substrato casca de pinus no desenvolvimento de mudas de grumixameira. Revista Brasileira de Fruticultura, Jaboticabal, v.33, nesp 1, p.643-648, 2011.

TAIZ, L.; ZEIGER, E. Fisiologia vegetal. 6.ed. Porto Alegre: Editora Artmed, 2017. 722 p.
TERRA, S.B.; BRAZ, G.M.; MENDES, F.B. Insumo alternativos para produção orgânica de mudas de hortaliças. Ambiência, Guarapuava, v.13, n.2, p.412-422, 2017.

VÉRAS, M.L.M.; de ARAÚJO, D.L.; de Sousa ALVES, L.; de Figueiredo ANDRADE, A.; ANDRADE, R. Combinações de substratos e urina de vaca no crescimento de tamarindo. Revista Terceiro Incluído, Goiânia, v.4, n.2, p.197-208, 2014.

VICENTINI, L.S., CARVALHO, K., RICHTER, A.S. Utilização de microorganismos eficazes no preparo da compostagem. Revista Brasileira de Agroecologia, Porto Alegre, v.4, n.2, p.3367-3370, 2009.

WRIGHT, I.J.; WESTOBOY, M. Cross-species relationships between seedling relative growth rate, nitrogen productivity and root vs leaf function in 28 Australian woody species. Functional Ecology, Oxford, v. 14, p. $97-107,2000$.

ZULFIQAR, F.; YOUNIS, A.; CHEN, J. Biochar or biochar - compost amendment to a peat-based substrate improves growth of Syngonium podophyllum. Agronomy, Basel, v.9, n.8, 460, 2019. 